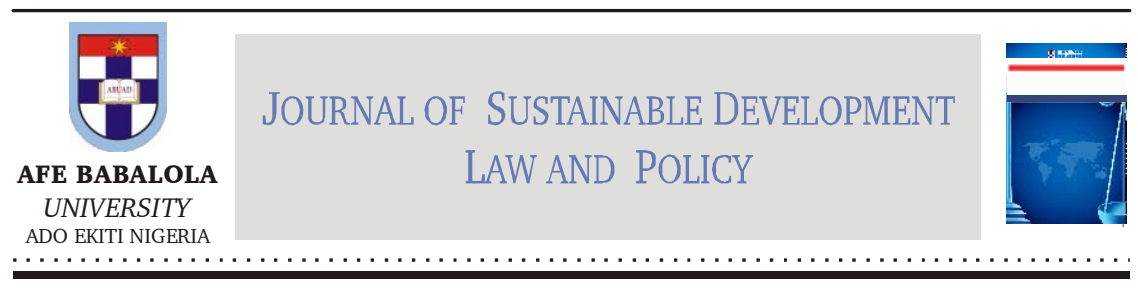

\title{
REDRESSING HARMFUL ENVIRONMENTAL PRACTICES IN THE NIGERIAN PETROLEUM INDUSTRY THROUGH THE CRIMINAL JUSTICE APPROACH
}

\author{
Cleverline T. Brown* \\ Nlerum S. Okogbule**
}

\begin{abstract}
The discovery and continued exploitation of crude oil in Nigeria with its many advantages, has exposed the Nigerian environment to several forms of pollution and degradation. Consequently, extensive harm has been done to the human and natural environment some of which may prove irreversible. This is largely attributable to wrongful environmental practices, sabotage, ineffective regulation and enforcement mechanisms. Sadly, environmental laws in Nigeria do not specifically criminalize such inimical activities, while some grave environmental crimes are downplayed and treated as civil wrongs. This article argues in favour of a compelling need for a reassessment of environmentally harmful acts with a view to codifying and criminalizing certain acts to promote the observance of basic environmental laws, especially by multinational corporations, and support the realization of a sustainable environment in the country. This has become imperative as Nigeria is a subscriber to the United Nations Sustainable Development Goals (SDGs). An effective and efficient regulatory regime is a vital for achieving these goals by the year 2030 .
\end{abstract}

* LL.B (RSU), B.L (Lagos), LL.M (RSU), Lecturer in Law, Rivers State University, Port Harcourt Nigeria and PhD Law Researcher, University of the West of England, Bristol, United Kingdom (UWE). E-mail: cleverline2.brown@live.uwe.ac.uk

** LL.B (Ife), B.L (Lagos), LL.M (Ife), PhD (Glasgow), Professor of International Law and Vice-Chancellor, Rivers State University, Port Harcourt, Nigeria. Email: nlerumokogbule@ust.edu.ng 
Keywords: Environment, Environmental Pollution, Environmental crime, Ecocide, SDGs.

DOI: https://dx.doi.org/10.4314/jsdlp.v11i2.3

\section{INTRODUCTION}

We and our environment are at risk. Air, water, and soil pollution; hazardous wastes disposal; global warming; acid rain; and reduction of the ozone layer threaten the natural environment and endanger people's health.

Yingyi Situ, David Emmons ${ }^{1}$

Various forms of harm have been perpetrated against the natural environment dating back to the pre-industrial era in history when wood was burnt to provide food, warmth and light. As necessary as it was back then, the first real harm that threatened the natural environment occurred through the period of the industrial revolution. ${ }^{2}$ The process required the manufacture of various products using raw materials that left vast hazardous wastes and pollution in its trail as evidence of the era. ${ }^{3}$ While modern civilization became the product of the industrial revolution, it set in motion the gradual process of the destruction of civilization as well. ${ }^{4}$ It is acknowledged that the industrial revolution is not ancient history and that it shaped lives in ways that are seldom appreciated. Indeed, the basic architecture of the built environment in

1 Y. Situ and D. Emmons, Environmental Crime: The Criminal Justice System's Role in Protecting the Environment (SAGE Publications 2000) 218, 1.

2 The Industrial Revolution began in the 18th century (1760 - 1830), when agricultural societies became more industrialized and urban. The transcontinental railroad, the cotton gin, electricity and other inventions permanently changed society. A \& E Television Networks LLC. "Industrial Revolution" (2018) <https://www.history.com/topics/industrial-revolution> accessed 13 October 2018.

3 Encyclopaedia Britannica. "Industrial Revolution" (2018) <https:// www.britannica.com/event/Industrial-Revolution> accessed 13 October 2018.

4 The scourge of environmental harm has, however, spread rather rapidly since the industrial revolution across the world as various nations of the world joined the race to civilization via industrialization. This has traversed the ordinary definition of environmental harm because of the ends, which it has been proved to attain, to metamorphose into environmental crime. 
which humans live and work was laid out in the industrial revolution era. ${ }^{5}$

The Nigerian environment has experienced untold and unrelenting assault on the natural environment. This has been perpetuated by way of the dumping of toxic wastes by foreigners ${ }^{6}$ and in the process of the exploration and exploitation of the vast natural resources found in the country. ${ }^{7}$ While laws were enacted to tackle the issue of environmental pollution, it was always done out of necessity and after the fact of pollution rather than proactively. ${ }^{8}$ To date, there is hardly any Nigerian environmental legislation that has codified environmental pollution or damage and criminalized corporate bodies that perpetrate it. Most environmental laws in Nigeria that prohibit damage to the environmental impose monetary sanctions on them, thereby reducing the severity of this wrongdoing against the state. ${ }^{9}$

In our opinion, this could be attributed to the inadequate appreciation of the severity of environmental damage and the extent to which and how such matters are decided upon by the courts. This article considers the concept of environmental crime and environmental harm and how the poor handling of these issues has weakened the environmental regulatory architecture in Nigeria consequently weakening the contribution towards achieving the Sustainable Development Goals. It

5 J.A. Rodden, "The Long Shadow of the Industrial Revolution: Political Geography and the Representation of the Left" (Stanford University 2012) 1, 6.

6 Dumping of toxic wastes by an Italian businessman in the village of Koko in the former Bendel state of southern Nigeria in 1988.

7 One of such examples is the massive oil spill that occurred in Ogoni land for almost fifty years while petroleum production was effectively going on in the region. Also recorded were several oil well blowouts, oil pipelines explosions and archaic equipment failure as well as oil infrastructure sabotage.

8 For example, the promulgation of the Decree No 42 of 1988 that created the Federal Environmental Protection Agency was made pursuant to the environmental disaster that followed the Koko incident. In 1987 an environmental disaster which occurred in Nigeria sent the country and the international community reeling. There was national public outcry over the dumping of over 3,500 tonnes of industrial waste by an Italian company which turned to be toxic waste. The substances contaminated the land and water of the Koko community, in the old Bendel State of southern Nigeria, resulting in the death of human beings, animals and destructions of acres of farmland and watercourses. See A. Nabegu, A.B. Mustapha and A.I. Naibbi, "Environmental Regulations in Nigeria: A Mini Review" (2017) 1(5) International Journal of Environmental Sciences and Natural Resources 1, 1.

9 Prohibition of gas flaring and the penalty for oil spillage. 
also considers judicial attitude to environmental crime and the attendant environmental harm. However, judicial attitude relies heavily on the legal framework for the prohibition of environmental harm in Nigeria. It is suggested that a progressive application of the criminal justice approach through the criminalization of environmental crime and harms will improve the quest for a more sustainable environment in Nigeria with a view to achieving the SDGs. ${ }^{10}$ This article also considers the environmental crime of ecocide as one of the main causes of environmental harm, while the pictorial depiction of incidents of environmental harm in Nigeria through oil spillage is also displayed.

\subsection{Defining Environmental Harm and Environmental Crime}

In defining the terms environmental harm and environmental crime in their simplest forms, it will be much easier to break up the terms into their constituent parts, environment, harm and crime.

\subsubsection{Environment}

The term environment has never been confined to a definition as legal definitions of the environment reflect scientific categorization and groupings as well as political acts that incorporate cultural and economic considerations. While a basic scientific approach to the definition of the environment compartmentalizes it ${ }^{11}$ into the atmosphere, atmospheric deposition, soils and sediments, water quality, biology and humans, this scientific definition is transformed by political processes into legal definitions found in treaties and other legal instruments. ${ }^{12}$ The term environment describes the external surrounding in which a plant, or animal lives, which influences its development and behaviour ${ }^{13}$ and a

10 The United Nations Sustainable Development Goals (SDGs) is a 2016 United Nations shared vision of humanity and a social contract between the world's leaders and the people. This initiative is made up of 17 Goals to banish social ills by 2030 .

11 Although this compartmentalization has been challenged by the discipline of ecology. See D. Olawuyi, Principles of Nigerian Environmental Law (2nd Edtn, Afe Babalola University Press, 2015) 2-15.

12 P. Sands and others, Principles of International Environmental Law (3rd Edition edn, Cambridge University Press 2012) 926, 14.

13 J.M. Sinclair, Collins Concise Dictionary (D Treffry, A Isaacs and S Ferguson eds, 4th edn, HarperCollins Publishers 1999) 1740, 477. 
media of air, land and water. ${ }^{14}$ It has further been defined as everything which surrounds a spatial entity, abiotic or alive ${ }^{15}$ and includes the totality of space, time and socio-cultural settings of humans and other living organisms therein. ${ }^{16}$ The Stockholm Declaration in defining the term in reference to the natural and man-made components which are essential to the well-being and enjoyment of basic human rights and the rights to life and natural resources of the earth, including the air, water, land, flora and fauna and especially representative samples of natural ecosystems. ${ }^{17}$ In Nigeria however, the term environment was defined to include water, air, land and all plants and human beings or animals living therein and the interrelationships which exist among these or between any of them. ${ }^{18}$

\subsubsection{Environmental Harm}

Some scholars have used the term "environmental harm" interchangeably with "environmental crime". ${ }^{19}$ This is because like most concepts in environmental law, environmental crime does not lend itself to any specific definition, especially because no definition can be retrieved from international conventions. ${ }^{20}$ In conceptualizing environmental harm, White proposed three approaches. The Conventional criminology approach, the Ecological perspectives approach, and the Green criminology approach. ${ }^{21}$

14 D. Hughes and others, Environmental Law (4th edn, Reed Elsevier 2002) 725, 4.

15 P.M. Dupuy and J.E. Vinuales, International Environmental Law (Cambridge University Press 2015) 438, 24.

16 E.M. Ityavyar and T.T. Thomas, "Environmental Pollution in Nigeria: The Need for Awareness Creation for Sustainable Development" (2012) 4(2) Journal of Research in Forestry, Wildlife and Environment 92, 94.

17 Declaration of the United Nations Conference on Human Environment, Stockholm, 16 June 1972, UN Doc. A/CONF 48/14/Rev. 1 ("Stockholm Declaration"), preamble, para 1 and principle 2.

18 NESREA Act Cap N36 Laws of the Federation of Nigeria 2010, s 37.

19 R. White and D. Heckenberg, Green Criminology: An Introduction to the Study of Environmental Harm (Routledge 2014) 348, E. Orlando and T. Bergin, "Forging a Socio-legal Approach to Environmental Harms" in Emanuela Orlando and Tiffany Bergin (eds), Forging a Socio-legal Approach to Environmental Harms: Global Perspectives (Routledge 2017) 3.

20 A. Mistura, "Is There Space for Environmental Crimes Under International Criminal Law? The Impact of the Office of the Prosecutor Policy Paper on Case Selection and Prioritization on the Current Legal Framework" (2018) 43(1) Columbia Journal of Environmental Law 181, 196.

21 R White, "The Criminalization of Environmental Harm: Rob White Explores How Environmental Harm is Conceptualized and How It should be Tackled" (2008) 74(1) Criminal Justice Matters 35, 36. 
The Conventional criminology approach speaks to the conceptualization of harm from the point of view of legal instruments such as law, rules and international conventions. Under this approach, activities are either legal or illegal. ${ }^{22}$ Ecological perspectives approach accommodates the conceptualization of harm from the understanding of the interrelationship between species and the environment. Under this approach, the key issue is that of ecological sustainability and the categorization of social practices into benign and destructive practices. ${ }^{23}$ Green criminology approach conceptualizes harm from the point of view of justice for the effects of activities on human, ecological and animal rights and egalitarian concerns. This approach weighs different kinds of harm and violation of rights within the context of eco-justice framework. ${ }^{24}$

Environmental harm is a very broad concept that describes a physical or mental injury or moral wrongdoing to humankind and the health of other living organisms, or interference with the ecological system of which they form a part, including any human senses or human property. ${ }^{25}$ It can be caused by activities such as tree clearing, fishing, pollution, and mining, damming rivers, killing native animals, soil erosion and aircraft noise. ${ }^{26}$ Environmental harm is any adverse effect on the value of the environment, ${ }^{27}$ the environmental value being a quality or physical characteristic of the environment that is conducive to ecological health, or public amenity or safety. ${ }^{28}$ It has been noted that the differences in the conceptualization of environmental harm has been influenced by differences in social position such as class, gender, indigeneity, ethnicity, etc., and paradigmatic understanding of nature and human interests such as business, science, humanities, aesthetics and philosophy. ${ }^{29}$

\footnotetext{
ibid 36.

ibid.

ibid.

D. Hughes and others (n 14) 654.

6 Caxton Legal Centre, "Environmental Harm" (2016) < https://queenslandlaw handbook.org.au/the-queensland-law-handbook/living-and-working-insociety/laws-affecting-the-environment/environmental-harm/>accessed 14 October 2018.

27 s 14 Environmental Protection Act 1994. s 15 extends the definition to cover environmental nuisance to be any unreasonable interference or likely interference with an environmental value caused by: noise, dust, odour or light. an unhealthy, offensive or unsightly condition because of contamination.

29 White (n 21) 35.
}

28 ibids 9. 


\subsubsection{Crime}

A crime, on the other hand, portends different meanings to different sectors. A crime is perceived as an act prohibited under the criminal law of a state and codified as such. However, not all state punishments are part of the criminal law. ${ }^{30}$ Some examples are civil penalties and civil contempt of court. Williams defined a crime to be an act capable of being followed by criminal proceedings having a criminal outcome, and a proceeding or its outcome is criminal if it has certain characteristics which mark it as criminal. ${ }^{31}$ Simply put, a crime is what the criminal code says it is, a behaviour that is prohibited by the criminal code and criminals are persons who have behaved in some way prohibited by the criminal law. ${ }^{32}$

\subsubsection{Environmental Crime}

An act is not an environmental crime unless it violates an existing environmental law. Under the various environmental laws in Nigeria, the term environmental crime is not used, rather the term environmental violation is. Environmental violation (crime) is expressed to be an activity or an existing condition that does not comply with environmental law or regulation. This can include but is not limited to smoke or other emissions from local industrial facilities; tampering with emission control, improper treatment, storage, or disposal of hazardous wastes; exceeding pollutant limits at publicly-owned wastewater treatment plants; unpermitted dredging or filling of waters and wetlands; any unpermitted industrial activity; late-night dumping or any criminal activity, including falsifying reports or other documents. ${ }^{33}$

Environmental crime, therefore, is defined as an unauthorized act or omission that violates the law and is, therefore, subject to criminal prosecution and criminal sanction. This unauthorized act, which typically serves the interests of organizations, government or individuals, harms

30 G. Lamond, "What is a Crime?" (2007) 27 (4) Oxford Journal of Legal Studies 609.

31 G. Williams, "The Definition of a Crime" (1955) 8 (1) Current Legal Problems 107.

32 Situ and Emmons (n 1) 2.

33 NESREA, "Environmental Violations" (2018) < http://www.nesrea.gov.ng/ contact-us/environmental-violations/> accessed 18 October 2018. NESREA adopted the term environmental harm instead of environmental crime. 
or endangers people's physical safety or health as well as the environment itself. ${ }^{34}$ However, like most crimes, environmental crimes must be expressly prohibited under existing environmental law and codified as such. In other words, for an act to qualify as an environmental crime, it must violate existing environmental laws, harm multiple victims and the environment and must be perpetrated by corporations, organizations (e.g. criminal combines or government agencies) as well as individuals. ${ }^{35}$ However, in Nigeria, inadequate penalties are provided for under environmental and petroleum sector laws as punishment for violation of the provisions. ${ }^{36}$ It is argued that since the main culprits of these violations are corporate bodies, such paltry fines are usually easy for the corporate bodies to pay, thereby removing any hint of deterrence that may have been intended by the enactment.

Therefore, it can be said that environmental crimes result in environmental harm but not all environmental harm results in environmental crime. ${ }^{37}$ A peculiar feature of environmental crime is that it throws up multiple victims as opposed to other forms of crime. The victims of environmental crimes are usually persons and the environment. ${ }^{38}$ Another feature is that environmental crimes can be perpetrated by corporations, groups, government agencies, businesses and individuals. ${ }^{39}$ Some scholars have taken the position that environmental crime should cover activities that may be lawful or licenced,

34 Situ and Emmons (n 1) 3.

35 Situ and Emmons (n 1) 4.

36 For example, s 27 (2). A fine of one million Nigerian naira or a jail term of five years is the penalty for air, land and sea pollution by an individual and S 27 (3) or one million Nigerian naira if pollution is at the instance of a body corporate.

37 M Clifford and TD Edwards, "Defining Environmental Crime" in Mary Clifford (ed), Environmental Crime: Enforcement, Policy, and Social Responsibility (Criminal Justice Series, Jones \& Bartlett Learning 1998) 5, 23. The authors highlighted the important requirement of the intent factor as a criminal element by defining environmental crime as an act committed with the intent to harm or with the potential to cause harm to ecological and or biological systems and for securing business or personal advantage.

38 Situ and Emmons (n 1) 4.

39 C. Gibbs and R. Boratto, "Environmental Crime", Oxford Research Encyclopaedia Criminology and Criminal Justice (Oxford University Press 2017) 1, 13. For example, corporations can dump hazardous contaminants illegally, local governments can ship solid wastes to prohibited sites and individuals can contribute to the destruction of protected forest and wild life. 
but which cause significant environmental harm. ${ }^{40}$ It is argued that if multinational corporations are not properly regulated in their conduct of their operations, their actions can hamper the overall government efforts at sustainable development.

\subsection{Legal Framework for Prohibition of Environmental Harm in Nigeria}

There are several laws on environmental and petroleum-related regulation in Nigeria. Some of these laws and regulations include Oil Pipelines Act, ${ }^{41}$ Mineral Oils (Safety) Regulations (1963), Oil in Navigable Waters Act, ${ }^{42}$ Petroleum Act, ${ }^{43}$ Associated Gas Re-injection Act, ${ }^{44}$ the National Environmental Standards and Regulations Enforcement Agency (NESREA) Act, ${ }^{45}$ the National Oil Spill Detection Response Agency (NOSDRA) Act, ${ }^{46}$ the National Policy on Environment 1989, 47 Environmental Impact Assessment (EIA) Act ${ }^{48}$ and the Department of Petroleum Resources (DPR)initiated Environmental Guidelines and Standard for the Petroleum Industry in Nigeria (EGASPIN) (2002).${ }^{49}$ EGASPIN was revised first in 2016 and then 2018, which is the current version.

The existence of these laws, however, has not done much to mitigate the environmental problems being experienced in the country due to

40 S. Bell and others, Environmental Law (9th edn, Oxford University Press 2017) 809, 267. See D. Olawuyi, Principles of Nigerian Environmental Law (2nd Edtn, Afe Babalola University Press, 2015) 2-15.

41 Cap O7 Laws of the Federation of Nigeria 2010 as amended by the Oil Pipeline Act of 1965 drafted into CAP 338 of the Laws of the Federation of Nigeria (LFN) 1990.

42 Cap O6 Laws of the Federation of Nigeria 2010.

43 Cap P10 Laws of the Federation of Nigeria 2010.

44 Cap A26 Laws of the Federation of Nigeria 2010.

45 Cap N36 Laws of the Federation of Nigeria 2010. This law repealed the Federal Environmental Protection Act of 1988,

46 Cap N63 Laws of the Federation of Nigeria 2010.

47 Revised in 1999, 2006 and 2010.

48 Cap E12 Laws of the Federation of Nigeria 2010.

49 A.E. Ite and others, "Petroleum Exploration and Production: Past and Present Environmental Issues in the Nigeria's Niger Delta" (2013) 1(4) American Journal of Environmental Protection 78, 81. The EGASPIN has been recently updated in 2018. For an analysis of EGASPIN 2018, see Damilola Olawuyi and Zibima Tubodenyefa, "Review of the Environmental Guidelines and Standards for the Petroleum Industry in Nigeria (EGASPIN)" (2018). 
legal, ${ }^{50}$ non-legal, ${ }^{51}$ and institutional factors. ${ }^{52}$ Most of the environmental and petroleum sector laws in Nigeria were enacted in response to one form of disaster or another. ${ }^{53}$ Looking at what these laws have been able to achieve since their enactment raises the question on whether they were properly thought through before being enacted. It is argued that the existence of laws prohibiting environmental harm is not in itself enough to deter the perpetration or prevalence of environmental harm.

In Nigeria, environmental laws have been categorized into three, namely; framework environmental legislation, sectoral legislation and incidental legislation. ${ }^{54} \mathrm{~A}$ framework environmental legislation is a single law which contains a comprehensive class of laws for environmental management. ${ }^{55}$ The sectoral legislation addresses specific aspects of the environment and human activities. ${ }^{56}$ Incidental legislations are those laws

50 The legal factors include conflicting, vague, and unenforceable legal provisions and punitive provisions that do not create the required deterrence. See B. Faturoti, G. Agbaitoro and O. Onya, "Environmental Protection in the Nigerian Oil and Gas Industry and Jonah Gbemre v. Shell PDC Nigeria Limited: Let the Plunder Continue?" (2019) 27(2) African Journal of International and Contemporary Law 225, 244.

51 The non-legal factors include social, economic and political factors. See T. Bodo, "Community Understanding of the Environmental and Socio-Economic Consequences of Petroleum Exploitation in Ogoni, Rivers State, Nigeria" (2018) 2(11) International Journal of Advanced Research and Publications 51, 51.

52 The institutional factors include overlapping functions of statutory regulatory agencies, non-existent national environmental database, poor resource allocation, corruption and bad governance. See O. Fagbadebo, "Corruption and the Challenge of Accountability in the Post-Colonial African States: A Discourse" (2019) 8(1) Journal of African Union Studies 9, 14.

53 The turning point in environmental legislation was in 1988 following the toxic waste incident in the village of Koko in the former Bendel State of Nigeria. This incident led to the enactment of FEPA Act in 1988; A. Ogunba, "An Appraisal of the Evolution of Environmental Legislation in Nigeria" (2016) 40(3) Vermont Law Review 673, 685.

54 O.C. Eneh and V.C. Agbazue, "Protection of Nigeria's Environment: A Critical Policy Review" (2011) 4(5) Journal of Environmental Science and Technology 490, 493.

55 Examples of framework environmental legislation include the Harmful Waste (Special Criminal Provision) Act Cap H1 Laws of the Federation of Nigeria 2010; Federal Environmental Protection Act now repealed by the National Environmental Standards and Regulations Enforcement Agency Act Cap N36 Laws of the Federation of Nigeria 2010 and National Oil Spill Detection and Response Agency Act Cap N63 Laws of the Federation of Nigeria 2010.

56 Examples of sectoral legislation include the Oil Pipeline Act (1956) as amended in 1965, now Cap $O 7$ laws of the Federation of Nigeria 2010; Associated Gas- 
that are not specifically intended to address environmental issues but contain some elements that have an impact on environmental issues. ${ }^{57}$

Some industry-specific laws in Nigeria are enacted for specific prohibitive reasons. One such law is the Petroleum Regulations 1967 made pursuant to the Petroleum Act 1969 which prohibits the discharge of petroleum into waters; ${ }^{58}$ Oil in Navigable Water Act No, 34 of 1968, which implements Nigeria's adherence to Convention for the Prevention of Sea Pollution; Petroleum (Drilling and Production) Regulation 1969 which sets out Petroleum Refining Regulations to be observed within the refining industry and deals with prevention of oil pollution, wellabandonment procedure and conduct of operations. ${ }^{59}$ Other laws exist that are not industry-specific but are relevant because of the significance of such laws. An example of such law is the Constitution of the Federal Republic of Nigeria 1999. Under the Fundamental Objectives and Directive Principles of State Policy, the Constitution requires the government to ensure the protection and improvement of the environment and safeguard the water, air, and land, as well as the forest and wildlife of Nigeria. ${ }^{60}$

In the penalty provisions of the environmental and petroleum sector laws, most sanctions are reduced to penalties in the form of paltry sums and scarcely has there been a recorded conviction culminating in a jail term sentence for offences against these laws. ${ }^{61}$ This is largely because most of the penalty sections of the environmental regulatory laws in

Reinjection Act Cap A26 Laws of the Federation of Nigeria 2004; and Oil in Navigable Waters Act 1968 now Cap O6 Laws of the Federation of Nigeria 2010.

57 Examples of incidental legislation include the Criminal Code 1916 now Cap C38 Laws of the Federation of Nigeria 2004 and Public Health Act 1917 now Cap P40 Laws of the Federation of Nigeria 2004.

58 Regulation 13 Petroleum Regulation.

59 Part II, regulations 25048; ibid (n 1) 95.

601 s 20.

61 S 6 Oil in Navigable Waters Act stipulates a fine of N2,000 for the discharge of crude oil, fuel, lubricating oil or heavy diesel oil into prohibited sea areas (s 1), discharge of oil into waters of Nigeria (s 3) and failure equipment in ships to prevent pollution (s 5). Under the Associated Gas Re-Injection Act, where a company continues to flare gas produced together with oil, the penalty is for the company to forfeit its concession in the particular fields in which the offence was committed. No forfeiture has been recorded to that effect, rather the government has continued to extend the terminal date for gas flaring in Nigeria and gas flaring, despite the obvious harm done to the atmosphere and a colossal loss of revenue, has continued unabated in Nigeria. The recent extension was in 2017 when the federal government shifted the terminal date from 2020 to 
Nigeria only provide for monetary sanctions, especially where corporations are envisaged as the offenders. ${ }^{62}$ Where provisions are made for terms of imprisonment as a penalty for contravening such laws, it was usually made in respect of offenders who are human persons. ${ }^{63}$ However, it is argued that the provisions concerning individual persons are redundant. This is because the offences envisaged by the NESREA Act are offences that are more likely to be committed by corporate bodies than by individuals. Looking at the NESREA Act, it is argued here that it is possible that the authors of the law did not consider that including a provision for imprisonment as it concerns corporate bodies could possibly create a stronger deterrence; although this would have required the law to go further and spell out the procedure to determine the mode of implementing this imprisonment term. While the categorization of offenders and their corresponding punishment are clearly spelt out in the NESREA act, the NOSDRA Act was not that explicit. It simply construes an offender as an "oil spiller" and only provides for monetary penalties ${ }^{64}$ when indeed individuals have been seen in recent times to spill oil as well, especially during sabotage.

Sadly, even with the enactment of the NESREA Act in $2007,{ }^{65}$ which was specifically targeted at enforcement and which empowers the Agency

2030. Apart from deciding that dealing in petroleum products without a licence is a criminal in the case of $M V$ Long Island $v$ Federal Republic of Nigeria (2018) LPELR (CA) 24 where the licence tendered by the MV Long Island were found to be expired, there has not been an actual licence forfeiture. In 2017 the court ordered the temporary forfeiture and transfer of operations of a long-disputed oilfield owned by SPDC and AGIP Eni among others, pending when the Nigerian anti-graft agency concludes investigation to the acquisition in 2011 of the oil prospecting licence (OPL) 245. Reuters. "UPDATE 2-Nigeria Court Orders Temporary Forfeiture of Shell, Eni Oilfield in Corruption Probe" (2017) < https:/ /www.reuters.com/article/nigeria-oil/update-2-nigeria-court-orderstemporary-forfeiture-of-shell-eni-oilfield-in-corruption-probeidUSL5N1FG757> accessed 18 October 2018.

62 NESREA Act ss 20 (4), 21 (3), 22 (4), 23 (4), 24 (5), 26 (4), and 27 (3).

63 See NESREA Act ss 20 (3), 22 (3), 23 (3), 24 (4), 26 (3), and 27 (2).

64 See NOSDRA Act S 6 (2) and (3).

65 This law repealed the Federal Environmental Protection Agency Decree No 58 of 1988 and 59 (amended) of 1992 which was a direct response to the incidence of the illegal dumping of toxic waste in the village of Koko in old Bendel state of Nigeria, whose main focus, as reaffirmed by the NESREA Act, was to protect the environment, enforce laws and regulations on the environment, maintain environmental standards, create environmental awareness and engage in partnership in environmental protection. 
to create modalities to ensure environmental awareness and compliance in Nigeria, ${ }^{66}$ the agency has continued to suffer the fate of its predecessor the Federal Environmental Protection Agency (FEPA). Some of the reasons why FEPA failed are poor enforcement of environmental laws and inadequate enforcement mechanisms. Compliance monitoring was through physical visits to facilities and this was unsustainable. As such, the environment suffered more from the activities of oil sector operators regardless of the existence of FEPA. ${ }^{67}$

In modern societies, law is the primary mechanism through which the environment can be regulated and protected from harm. This is challenged by the conspiracy of silence between multinational corporation and the government regarding environmental violations and this is underpinned by sustaining this collusion with the resources of the power elite. ${ }^{68}$ While it does appear that Nigeria has covered the basics in respect of laws prohibiting environmental harm, the existing laws have proved to be inadequate to regulate the environment and the operations of the petroleum industry. This shortcoming has been reflected widely in the following incidents of environmental pollution in the operations of the petroleum industry in Nigeria as recorded by the Oil Spill Monitor ${ }^{69}$ which holds data collected by various oil companies monitored by NOSDRA.

\subsection{Culprits of Environmental Harm}

While it is conceded that pipeline failures and oil spills have occurred due to structural problems, operational error, external force damage, control problems and other factors, including sabotage and equipment age ${ }^{70}$ there have been arguments as to who the worse culprit of environmental harm is. Mba et al have held the view that in the last

66 V.E. Agbazue, E.K. Anih and B.U. Ngang, "The Role of NESREA Act 2007 in Ensuring Environmental Awareness and Compliance in Nigeria" (2017) 10 (9) IOSR Journal of Applied Chemistry 32, 35.

67 M.T. Ladan, "Review of NESREA Act 2007 and Regulations 2009-2011: A New Dawn in Environmental Compliance and Enforcement in Nigeria" (2012) 8(1) Law Environment and Development Journal (LEAD) 118, 120.

68 M.J. Greife and M.O. Maume, "Do Companies Pay the Price for Environmental Crimes? Consequences of Criminal Penalties on Corporate Offenders" (2020) 73(3) Crime, Law and Social Change 337, 352.

69 www.oilspillmonitor.ng

70 C.H. Achebe, U.C. Nneke and O.E. Anisiji, "Analysis of Oil Pipeline Failures in the Oil and Gas Industries in the Niger Delta Area of Nigeria" (2012) 2 International Multiconference of Engineers and Computer Scientists 1, 5. 
decade, third parties are now more culpable in environmental pollution through sabotage of petroleum installations and equipment thereby causing more environmental harm. ${ }^{71}$ This position is arguable in the sense that prior to the discovery of petroleum in Nigeria there were no records of environmental harm due to oil spill incidents. It is contended here that when the petroleum sector was almost non-existent and the Nigerian economic focus was on trade and agriculture, there were hardly any instances of environmental harm from petroleum sector operations. Again, the data displayed by NOSDRA on its oil spill monitor website tells a different story from Mba's assertion.

From the wording of the penalty section of the Petroleum Production and Distribution (Anti-Sabotage) Act, ${ }^{72}$ it does appear that the offenders envisaged in the offence of sabotage and oil crimes are individuals or groups of persons that can be sentenced to death or committed to prison, if found guilty. ${ }^{73}$ However, this still leaves the biggest culprits of environmental harm, the multinational corporations, with much leg room to continue their unbridled display of disregard for the environment. The elusive deterrent effect of corporate criminal sanctions cannot be overemphasized. ${ }^{74}$ It has been opined that although corporate behaviour is oriented towards perceived risks and rewards, it is less sensitive to the law's conventional sanctioning threats than the classic model of deterrence would suggest. ${ }^{75}$

\section{INCIDENTS OF ENVIRONMENTAL POLLUTION IN NIGERIA}

Environmental pollution is not peculiar to any nation but happens in both developed and developing nations. ${ }^{76}$ However, since the focus of

71 I.C. Mba and others, "Causes and Terrain of Oil Spillage in Niger Delta Region of Nigeria: The Analysis of Variance Approach" (2019) 9 (2) International Journal of Energy Economics and Policy 283, 287.

72 Cap P12 Laws of the Federation of Nigeria 2010.

73 S 2 Cap P12 Laws of the Federation of Nigeria 2010.

74 PC Yeager, "The Elusive Deterrence of Corporate Crime" (2016) 15(2) Criminology \& Public Policy 439.

75 SS Simpson, Corporate Crime, Law and Social Control (A. Blumstein ed, Cambridge University Press 2002) 180.

76 Examples are rife in Nigeria in the pollution experienced as a result of the Ogoni oil spill. In the United States of America, the Exxon Valdez oil spill incident occurred when 11 million gallons of crude oil was spilled into Alaska's Prince William Sound in March 1989 covering 1,300 miles of coastline, killing hundreds of thousands of seabirds, otters, seals and whales. 
this article is on the situation in Nigeria, this section will discuss some of the instances of environmental pollution from petroleum operations that have resulted in environmental harm to the environment and to human life in the country.

Environmental pollution due to oil spill in Nigeria has been recorded in over a thousand sites. ${ }^{77}$ Oil spills can be accidental or perpetrated deliberately during oil drilling operations, transportation, through leakages, and through sabotage of oil facilities. ${ }^{78}$ In the process, substances are introduced into the surrounding environment, marine environment, coastal zones, and related inland waters resulting in such deleterious effects as destruction of farmland, harm to living resources, hazard to human health, hindrance to marine activities, including fishing, impairment of the quality of sea-water and reduction of amenities. ${ }^{79}$

It is pertinent to note that environmental pollutions are of various types and causes. The main types of environmental pollution in Nigeria include water or aquatic pollution, air or atmospheric pollution and land or surface area pollution. ${ }^{80}$ Other identified types of pollution are thermal pollution, radiation pollution and noise pollution. ${ }^{81}$ There are also various sources of environmental pollution such as oil spills, oil well blowouts, effluent emission (gas flaring), equipment failure, abandoned oil facilities, artisanal refining (oil bunkering), and improper industrial waste disposal.

While many studies have shown the various types of environmental pollution incidents due to oil operations in Nigeria, the most instructive record of such incidents is that collated and kept by the National Oil Spill Detection and Response Agency (NOSDRA). The Agency has located 8,486 oil spill incidents out of 12,672 spills reported via the Oil Spill

77 Ityavyar and Tyar (n 16) 92, Ityavyar and Thomas defined environmental pollution as an undesirable change in the environment due to the application of harmful substances; waste materials and resources, caused by man's activity or natural disasters which also results to the degradation of the environment with its attendant consequences on biodiversity.

78 M. Khamehchiyan, A.H. Charkhabi and M. Tajik, "Effects of Crude Oil Contamination on Geotechnical Properties of Clayey and Sandy Soils" (2007) 89 (3-4) Engineering Geology 220.

79 Article 2 (1) Convention for Co-Operation in the Protection and Development of the Marine and Coastal Environment of the West and Central African Region; and Protocol (1981).

80 C.T. Isife, "Environmental Problems in Nigeria - A Review" (2012) 4 (1 \& 2) Sustainable Human Development Review 21, 29.

81 Ityavyar and Tyar (n 16) 93. 
Monitor website. ${ }^{82}$ Spills caused by oil company failure are expressed in black, spills caused by third-party theft or interference are expressed in red, and spill sites which have been reported but not visited are expressed in purple. ${ }^{83}$

\subsection{Oil Spills Sites Satellite View}

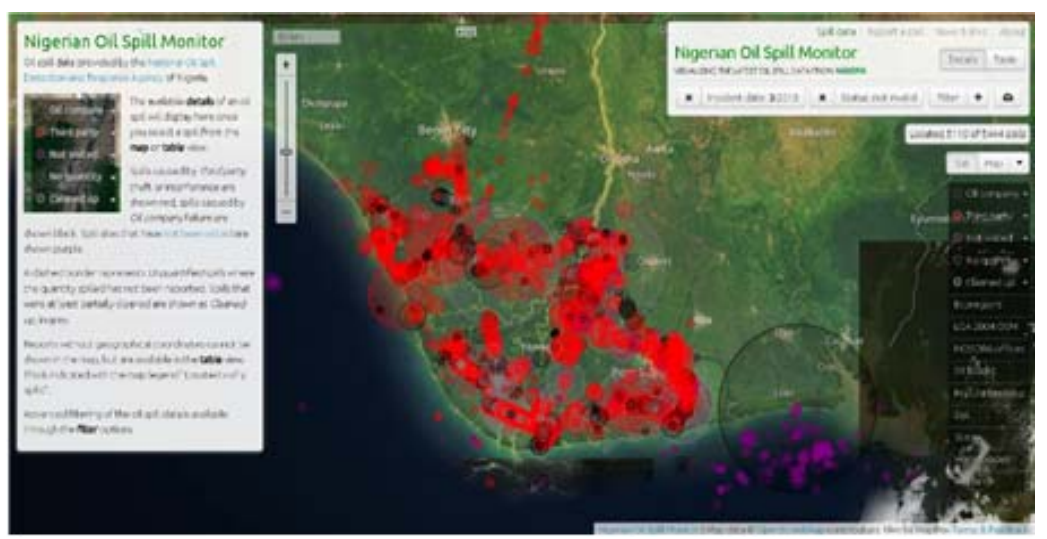

Fig. 1

Source: NOSDRA via the Nigerian Oil spill Monitor 2018 https:// oilspillmonitor.ng/

\subsection{Oil Spill Sites Map View}

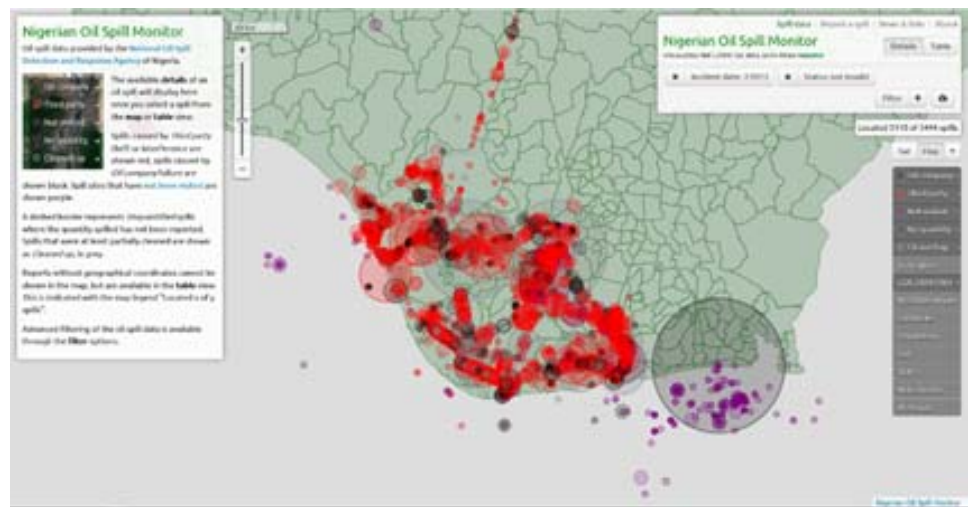

Source: NOSDRA via the Nigerian Oil spill Monitor 2018 https:// oilspillmonitor.ng/

82 https://oilspillmonitor.ng/

83 ibid. 
This picture expresses the satellite and map views of the different incidents of oil spills due to various causes.

\subsection{Oil Spills Caused by Company Failure}

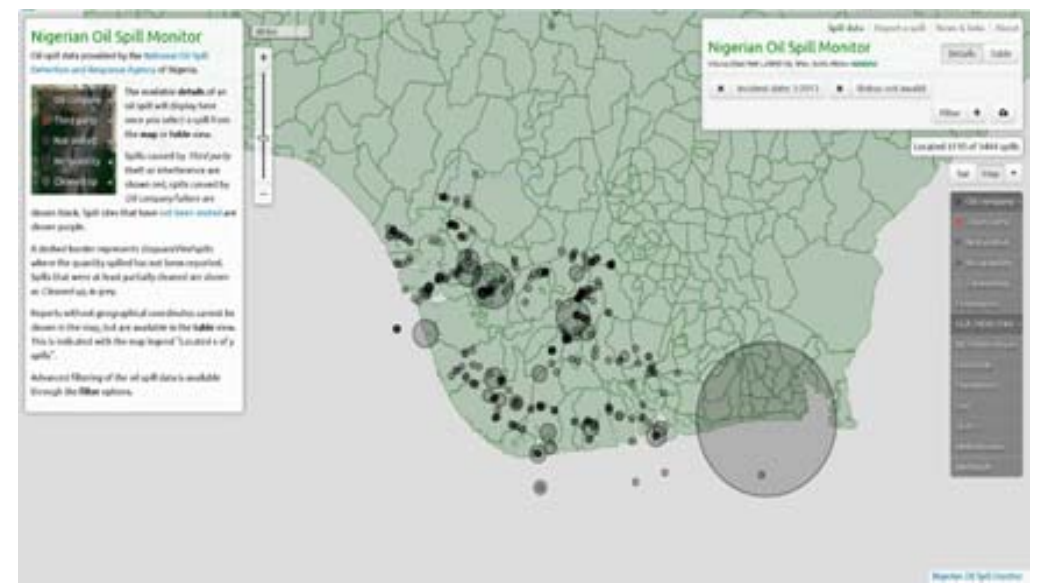

Source: NOSDRA via the Nigerian Oil spill Monitor 2018 https:// oilspillmonitor.ng/

The above picture illustrates the incidents of the oil spill caused by oil companies mostly due to equipment failure and negligence.

\subsection{Oil Spills Caused by Third Parties}

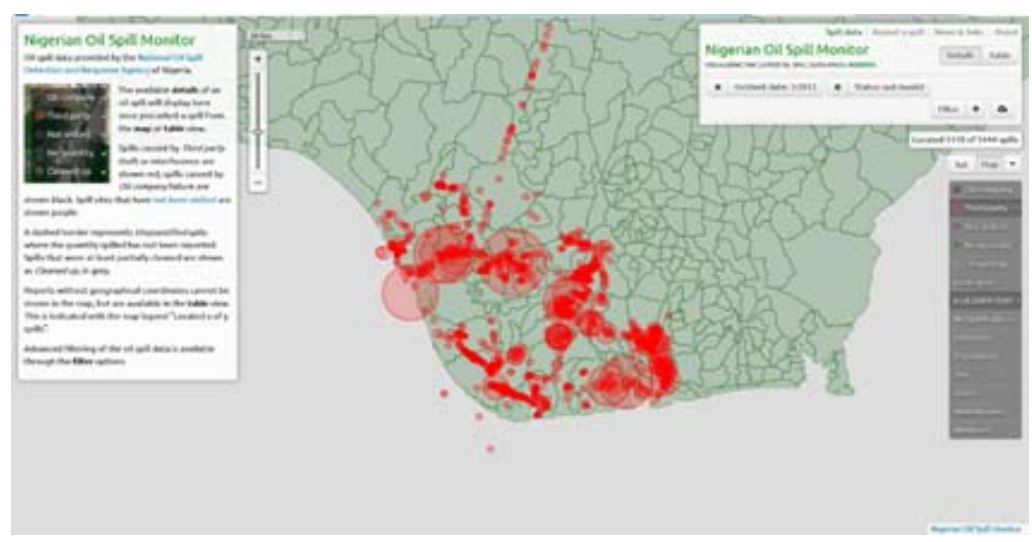

Fig. 2

Source: NOSDRA via the Nigerian Oil spill Monitor 2018 https:// oilspillmonitor.ng/ 
This picture depicts the map view of the oil spill sites where spills were attributed to the activities of oil thieves, third party interference with oil installations and sabotage or militant activities. At the time of the writing of this article, the most recent incident was the oil pipeline fire outbreak at Aba, Abia State of Nigeria allegedly caused by suspected oil thieves who had hacked into the pipeline to intercept the flow of petrol from Port Harcourt to Aba on 12 October 2018. ${ }^{84}$

\subsection{Oil Spill Sites Not Visited}

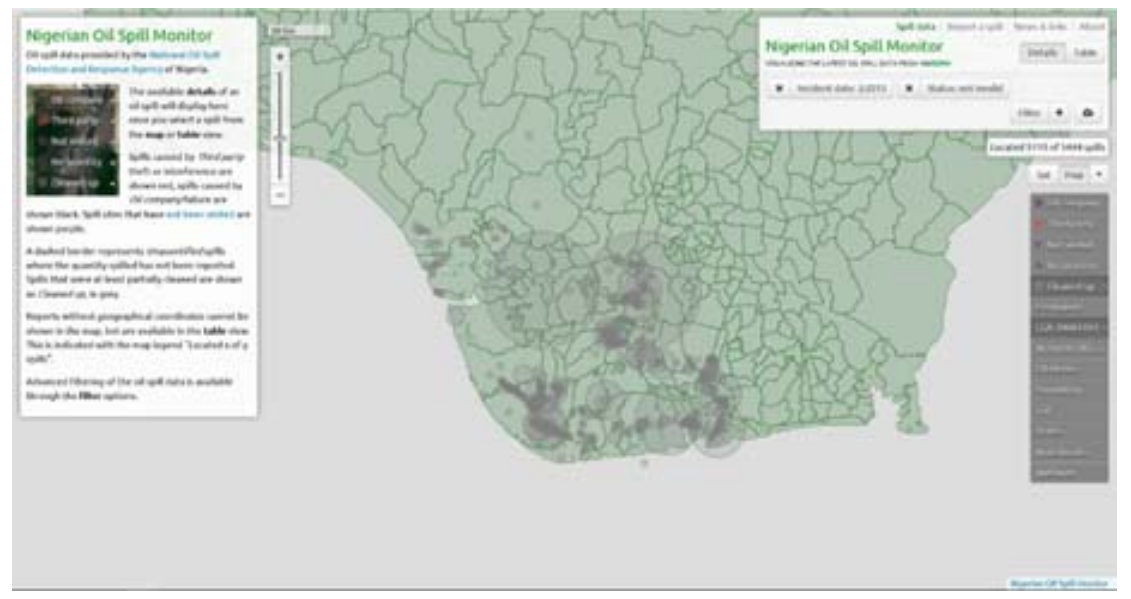

\section{Fig. 3}

Source: NOSDRA via the Nigerian Oil spill Monitor 2018 https:// oilspillmonitor.ng/

The above picture depicts the incidents of oil spill locations reported to NOSDRA but sites have not been visited for assessments due to lack of the required facilities and logistics to visit such sites.

84 Nigerian National Petroleum Corporation. "NNPC Moves to Contain Oil Pipeline Fire Outbreak at Osisioma, near Aba" (2018) < http://www.nnpcgroup.com/ PublicRelations/NNPCinthenews/tabid/92/articleType/ArticleView/articleId/ 1084/NNPC-Moves-to-Contain-Oil-Pipeline-Fire-Outbreak-at-Osisioma-NearAba.aspx $>$ accessed 18 October 2018. This incident reportedly claimed about 150 lives. 


\subsection{Partially Cleaned Up Oil Spill Sites}

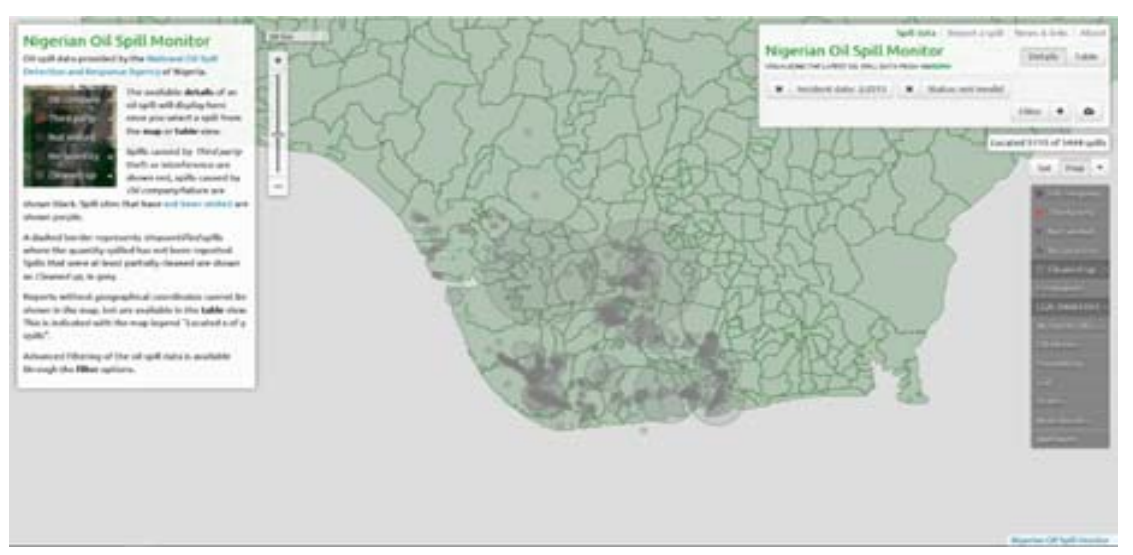

Fig. 4

Source: NOSDRA via the Nigerian Oil spill Monitor 2018 https:// oilspillmonitor.ng/

The above picture depicts the oil spill sites partially cleaned up.

It is contended that the admission of NOSDRA that it relies on the voluntary engagement and support of oil companies to provide logistics, data, quantity estimates, soil/water samples and carry out clean-up operation of the spill sites raises a number of pertinent issues. ${ }^{85}$ First, while these illustrations exist, the admission casts serious doubt on the reliability of the generated and expressed data because this admission on some level can render this data unreliable as it is not customary in the experience of the Nigeria petroleum industry for industry operatives to admit to their own faults. Second, with the retinue of environmental legislation in Nigeria, most of which are directed towards environmental protection, its continued pollution by the introduction of harmful or unpleasant materials or energy that makes it impure and causes acute or chronic detriment to its ecological balance, lowers the quality of life of the organisms existing there. ${ }^{86}$

85 NOSDRA, "The Scale of the Problem and the Tasks Ahead" (2018) < https:// oilspillmonitor.ng/> accessed 18 October 2018.

861 A.O. Coker, "Environmental Pollution: Types, Causes, Impacts and Management for the Health and socio-Economic Well-being of Nigeria" (2008) <https://pdfs.semanticscholar.org/8e7b/a9595bab30d7ea87715533 353c53f7452811.pdf $>$ accessed 17 October 20181. 
While the above illustrations speak for themselves, only a handful of instances come to mind demonstrating the lack of diligence in dealing with oil spills in the country. For instance, the Shell Bonga oil spill of over 40,000 barrels of crude oil occurred in 2011 due to equipment failure and affected over 20 riverine communities across three Niger Delta states in Nigeria. NOSDRA fined Shell Petroleum Development Company (SPDC) US\$ 3.6 billion after an initial impact assessment report of the incident, but SPDC refused to accept full responsibility for the mishap ${ }^{87}$ and refused to pay the fine. ${ }^{88}$ This is one of the many examples of where the intervention of the judiciary becomes important. The following section discusses the attitude of the judiciary in its intervention in environmental and petroleum sector cases.

\section{JUDICIAL ATTITUDE TO ENVIRONMENTAL HARM}

It is the case that when environmental matters are brought to court, it is usually to ascertain the rights and obligations of victims and culprits of environmental violation. ${ }^{89}$ It is believed that the outcome of such matters is the medium through which the attitude of the judiciary towards decisions of operators of the petroleum sector in Nigeria can be gauged. One of the functions of the judiciary is to adjudicate on issues of conflicts and disagreements and decide one way or another. Some of the cases discussed below show that there is no consensus on the attitude of the judiciary in environmental and petroleum sector-related cases.

Failure to report an oil well blow out in 2012 that caused serious gas fire and oil spillage which continued for over 46 days and failure to clean up the impacted site in contravention of the provisions of the NOSDRA Act is the core of the matter in the case of NOSDRA $v$ Chevron

87 O.J. Olujobi, O.A. Oyewunmi and A.E. Oyewunmi, "Oil Spillage in Nigeria's Upstream Petroleum Sector: Beyond the Legal Frameworks" (2018) 8 (1) International Journal of Energy Economics and Policy 220, 222.

88 This resulted in Shell approaching the Federal High Court in Nigeria to declare the fine unconstitutional as it robbed the company of its constitutional right to fair hearing. The court however rejected the declaration and upheld the fine. As at November 2018, Shell was still procrastinating on the payment of the fine.

89 J.R. May and T. Dayo, "Dignity and Environmental Justice in Nigeria: The Case of Gbemre v. Shell" (2019) 25(2) Widener Law Review 269, 283. 
Nigeria Limited. ${ }^{90}$ In PPMC $v$ NOSDRA, ${ }^{91}$ after refusing to pay a fine levied against it by NOSDRA for refusal to report and clean up an oil spill pursuant to s 6 (2) and (3) of the NOSDRA Act, the PPMC filed a suit at the Federal High Court challenging the authority of NOSDRA to unilaterally levy fines in violation of its laws. The court held, among other things, that PPMC was in violation of $s$ (2) and (3) of the NOSDRA Act and NOSDRA rightfully levied the fine to that effect. However, in the case of NOSDRA $v$ Mobil Producing Nigeria Unlimited (ExxonMobil), ${ }^{92}$ the Federal High Court stripped NOSDRA of its power to unilaterally impose fines for contravention of its law. On appeal, the Court of Appeal affirmed the stripping of NOSDRA's power and authority to impose fines for contravention of the offences provision of the enabling act. ${ }^{93}$ The court held that the power to punish or impose fines must be preceded by a trial in which the rules of fair hearing must be observed. It was further held that a fine is a criminal sanction ordered by a court from a person who has been found guilty of violating the law and can be ordered as an option to imprisonment for major crimes or as a complement to other punishments specified for such crimes. ${ }^{94}$ This decision was made while there was a subsisting Court of Appeal decision affirming that regulatory bodies can impose penalties against offenders who contravene the provisions of its laws. This was the decision in the case of Moses Ediru $v$ Federal Road Safety Commission and 2 Others. ${ }^{95}$ Since the two decisions were reached by the same Court of Appeal, by law, the later decision in time remains the law until it is upturned at the Supreme Court or the Court of Appeal overrules itself. ${ }^{96}$ In this instance the 2018 decision in NOSDRA $v$ Mobil Producing Nigeria Unlimited (ExxonMobil) is the later in time and the position of the law.

90 NOSDRA $v$ Chevron Nigeria Limited (Unreported) Suit No FHC/AK/CS/13/2013.

91 Suit No. FHC/ASB/18/105/10 (Unreported).

92 (2018) Law Pavilion Electronic Law Report-44210 (LPELR (CA)

93 S 6 (2) and (3) NOSDRA Act; NOSDRA v Mobil Producing Nigeria Unlimited (ExxonMobil) (2018) Law Pavilion Electronic Law Report-44210 (LPELR (CA) in paragraph $C$ of page 9 of the judgement.

94 Abdullahi v Kano State (2015) LPELR-25928 (CA) per Abba Aji, JCA.

95 (2016) 4 NWLR Part 1502, 209.

96 It is the practice that when there two conflicting decisions on the same subject matter before the Court of Appeal, the Court can elect which one to follow when confronted with a similar case, however, a lower court is bound to follow the decision which is later in time. 
However, in the case of Shell Nigeria Exploration and Production Company Limited (Shell) v National Oil Spill Detection and Response Agency (NOSDRA $)^{97}$ before a Federal High Court, the Court departed from the decision of the Court of appeal in NOSDRA $v$ Mobil Producing Nigeria Unlimited (ExxonMobil) and held that NOSDRA can in fact impose sanctions without recourse to the Court. It is argued that this is an anomaly as the Federal High Court is a court of lower jurisdiction than the Court of Appeal and ought to follow the latest decision of the Court of Appeal on this subject. It is further argued that this position sends the wrong signal to both the regulatory bodies and the petroleum sector operators about the ability of a regulatory body to enforce compliance in line with its enabling laws without recourse to the courts. ${ }^{98}$

In the case of Oronto Douglas $v$ SPDC Limited \& $O r s^{99}$ which was essentially to ensure compliance with the provision of the Environmental Impact Assessment Act (EIA), ${ }^{100}$ the law suit was dismissed because the court held that there was no cause of action as the plaintiff did not allege a specific legal right violated by the defendants and did not have "sufficient interest" in the subject matter. ${ }^{101}$ Sufficient interest is interest

97 G. Ukwuoma, "Nigeria: Litigation Update - June 2018: Do Administrative Agencies Lack Powers to Impose Fines and Penalties without Recourse to the Courts? Matters Arising: Shell Petroleum Exploration and Production Company Ltd (SHELL) v National Oil Spill Detection and Response Agency (NOSDRA)" (2020) < https://www.advocaat-law.com/assets/resources/ 341e36a14b167a82e12df3ff9e6c4e3b.pdf> accessed 10 July 2020.

98 This stance is further confirmed where the judiciary reached two conflicting decision on the subject matter of the import of s 20 of the Constitution of the Federal Republic of Nigeria in the cases of Abacha $v$ Fawehinmi No 2 and Jonah Gbemre $v$ SPDC.

99 (1998) LPELR-CA/L/143/97 Law Pavilion Electronic Law Report - Court of Appeal.

100 Cap E12 Laws of the Federation of Nigeria 2004.

101 The plaintiff sought three reliefs: a declaration that the defendants cannot lawfully commission, carry out and operate their Liquefied Natural Gas Projects without first complying with the Environmental Impact Assessment Act 1992; a declaration the Attorney General of the Federation (5th Defendant) is bound to require the 1st, 2nd and 3rd Defendants (Shell, NNPC and NLNG) to make public the Environmental Impact Assessment report to any NGO and communities likely to be impacted by the project in line with the law; and an injunction restraining the 4th Mobil Producing Nigeria Unlimited (4th Defendant) from commencing or commissioning the LNG Project or any activity thereon pending a proper Environmental Impact Assessment of the project certified by the Attorney General of the Federation (5th Defendant) in line with the law. 
which is peculiar to the plaintiff as opposed to an interest which the plaintiff shares in common with other members of the public. ${ }^{102}$ The court took this stand even though it had been settled that a plaintiff can be accorded the standing to bring an action if he can show that his civil rights and obligations have been or are in danger of being violated or adversely affected by the act complained of. ${ }^{103}$ It has been argued that the trial judge did not consider the fact that the substance of the suit was of common and general interest to the citizens of Nigeria ${ }^{104}$ and in furtherance of the human right to a clean and safe environment as enshrined in the African Charter on Human and Peoples' Rights. ${ }^{105}$

The participation of Nigerians in their government is assured by the same Constitution of Nigeria that prioritizes the security and welfare of the citizens. ${ }^{106}$ This brings Oronto Douglas well within the definition of a person who has sufficient interest in the subject matter and whose constitutional right to a healthy environment is likely to be violated. It is believed that had this suit been decided otherwise, it would have been authoritative precedence to the stance of the judiciary on compliance and enforcement in the petroleum sector in Nigeria.

From the foregoing, it is contended that these decisions do not represent a progressive and positive development in the efforts to reign in operators of the petroleum sector in the country. It rather gives credence to the view of some writers that the Nigerian judiciary has been unduly sympathetic to the interests of operators in the oil and gas industry and the government while paying less attention to the rights of the citizens to a safe and healthy environment. To be sure, such decisions rather than deter the operators, have the potential of emboldening or encouraging them to continue to perpetuate harm on the environment during their operations.

The case of Jonah Gbemre $v$ Shell Petroleum Development Company

102 G.U. Ojo and T. Nosa, "Access to Environmental Justice in Nigeria: The Case for a Global Environmental Court of Justice" (2016) < https://www.foei.org/ wp-content/uploads/2016/10/Environmental-Justice-Nigeria-ShellEnglish.pdf $>$ accessed 18 June 2019, 4.

103 J.G. Frynas, "Legal Change in Africa: Evidence from Oil-Related Litigation in Nigeria" (1999) 43(2) Journal of African Law 121

104 T. Okonkwo, "Environmental Constitutionalism in Nigeria: Are We There Yet?" (2015) 13 The Nigerian Juridical Review 175, 206.

105 ibid.

106 S 14 (2) c Constitution of the Federal Republic of Nigeria 1999. 
$L t d^{107}$ however shows a different picture of where the judiciary exhibited firmness in defence of the environment. The case provided the opportunity to correct regulatory irregularities in some environmental and petroleum sector laws but failed to act proactively to ensure that the order of court was enforced, thereby losing the opportunity it hitherto created for a review in the law. ${ }^{108}$

In that case, the action was brought by Jonah Gbemre in a representative capacity on behalf of himself and the Iwherekan Community in Delta State, Nigeria, seeking an order to secure the enforcement of their fundamental rights to life and dignity of the human person pursuant to ss 33 (1) and 34 (1) of the 1999 Nigerian Constitution ${ }^{109}$ and Articles, 4, 16 and $24^{110}$ of the African Charter on Human and Peoples' Rights (Ratification and Enforcement) Act. ${ }^{111}$ Other reliefs sought by the applicants include a declaration that the continued gas flaring by the respondents violated the rights mentioned above. A declaration that failure to conduct an EIA in the community regarding the effect of the gas flaring activities violated provisions of the EIA Act consequently violating their right to life and dignity of the human person. An order declaring section 3 (2) (a) and (b) of the Associated Gas Re-injection Act $^{112}$ unconstitutional and void. An order of perpetual injunction restraining the respondents from further flaring of gas in the community.

The court made the following orders among others: First, that the continuous flaring of gas in the applicants' community impacted

107 Jonah Gbemre v Shell Petroleum Development Company Ltd [2005] 6 African Human Rights Law Report 152.

108 B. Faturoti, G. Agbaitoro and O. Onya, "Environmental Protection in the Nigerian Oil and Gas Industry and Jonah Gbemre v. Shell PDC Nigeria Limited: Let the Plunder Continue?" (2019) 27(2) African Journal of International and Contemporary Law 225.

109 S 33 (1) provides for the right to life and s 34 (1) provides for the right to respect for the dignity of human person.

110 Article 4 provides that every human being is entitled to respect for his life and the integrity of his person and no one may be arbitrarily deprived of this right. Article 16 provides for the right to enjoy the attainable state of physical and mental health. Article 24 provides that the right to a general satisfactory environment favourable to their development.

111 Cap A9 Laws of the Federation of Nigeria 2004; African Charter on Human and Peoples' Rights (Banjul Charter) 27 June 1981.

112 Under this section, gas flaring may be allowed by the minister of petroleum resources under certain conditions in direct violation of the applicants right to life and dignity of the human person. 
negatively on the right to life of the applicants and ordered that the respondents stopped the flaring of gas in that community. Second, that the Attorney General should commence proceedings to regularize the inconsistent provisions of the Associated Gas Re-injection Act to bring it to conformity with the 1999 Constitution regarding the right to life and dignity of the human person. While this judgement was hailed as a significant judgement in the sense that it sought to protect the human and natural environment and it outrightly declared gas flaring illegal, ${ }^{113}$ the order of court was eventually not implemented for some reasons, giving the respondents room to ignore the court order and continue flaring gas. ${ }^{114}$

From the discussions in this section, opinions are divided regarding the attitude of the judiciary in environmental and petroleum sectorrelated cases. For this reason, victims of environmental injustice seek alternative pathways to enforce their fundamental right to life and, by implication, this includes the right to live in a healthy environment. In Gbemre's case, the Federal High Court recognized that environmental degradation could give rise to a violation of human rights as envisaged under the African Charter on Human and Peoples Rights. Therefore, Articles 4, 16 and 24 of the African Charter on Human and Peoples Rights can be relied on to enforce environmental rights ${ }^{115}$ instead of relying on s $20^{116}$ of the Constitution of the Federal Republic of Nigeria, which is non-justiciable by virtue of s 6 (6) (c) of the same Constitution. ${ }^{117}$

113 Faturoti, Agbaitoro and Onya, (n 108) 234.

114 Upon the continued flaring of gas in the community, the applicants instituted contempt proceedings against the respondents. The court ordered the respondents to submit a detailed plan to achieve the cessation of gas flaring by April 2007. While this order was pending, the judge was transferred to another judicial division, thereby stripping him of the powers and jurisdiction to continue to hear the case.

115 Article 24 of the African Charter on Human and Peoples Rights provides that the right to a satisfactory environment for development is a human right.

116 S 20 of the 1999 Constitution provides for the obligation of the state to protect and improve the environment.

117 S 6 (6) (c) of the 1999 Constitution, precludes the Judiciary from hearing any matter that seeks to query whether any act or omission of any authority or person is in conformity of the provisions under Chapter 2 of the Constitution. See L.A. Atsegbua, "Environmental Rights, Pipelines Vandalisation and Conflict Resolution in Nigeria" (2001) International Energy Law \& Taxation Review 89, 92. 


\subsection{Alternative Pathways to Redressing Environmental Harm}

Victims of environmental harm face many challenges in trying to access justice in environmental and petroleum sector-related matters. ${ }^{118}$ This has consistently watered-down the confidence of such victims in the Nigerian courts as a result of social and environmental injustice. Due to these difficulties, some environmental cases are now taken to courts that are outside the shores of Nigeria. ${ }^{119}$ Some of the courts that have entertained such cases are the Courts of the United Kingdom, ${ }^{120}$ African Commission on Human and Peoples' Rights ${ }^{121}$ and the Economic Community of West African States (ECOWAS) Community Court of Justice subject to exhausting local avenues to remedy the injustice. While this is a welcome development, such courts do not always enjoy jurisdiction in every matter that comes before it. This was exhibited in the case of Socio-economic Rights and Accountability Project (SERAP) $v$ President of the Federal Republic of Nigeria \& Ors. ${ }^{122}$ In that case, the court held that while it had jurisdiction to entertain the case, its jurisdiction was only to the extent that the federal government of Nigeria and its agency the Nigeria National Petroleum Company (NNPC) are parties to ECOWAS treaties; but that it lacked jurisdiction over multinational corporations and proceeded to strike their names off the law suit. ${ }^{123}$

The attraction of seeking justice in other jurisdictions has been further cemented in the recent foreign case of Vedanta Resources Plc and Another $v$ Lungowe and Others. ${ }^{124}$ In that case, the UK Supreme Court held that

118 These challenges include high cost of litigation, poverty and ignorance, locus standi, delay in justice delivery, technicalities in the law, cumbersome judicial process, the multiplicity of environmental legal instruments, etc.

119 E.O. Popoola, "Moving the Battlefields: Foreign Jurisdictions and Environmental Justice in Nigeria" < https://items.ssrc.org/...environments/ moving-the-battlefields-foreign-jurisd...> accessed 19 August 2019.

120 Okpabi $v$ Royal Dutch Shell and Others [2018] EWCA Civ 191.

121 Article 50 of the African Charter on Human and Peoples' Rights.

122 Socio-Economic Rights and Accountability Project (SERAP) $v$ President of the Federal Republic of Nigeria \& Ors ECW/CCJ/APP/08/09.

123 The proceedings of this case reaffirm the impartiality of the judiciary in the case in question. E.O. Ekhator, "Improving Access to Environmental Justice Under the African Charter on Human and Peoples' Rights: The Roles of NGOs in Nigeria" (2014) 22 (1) African Journal of International and Comparative Law 63, 73.

124 [2019] UKSC 20. 
UK courts can assume jurisdiction in certain circumstances, over cases instituted in UK Courts by non-UK citizens against both foreign subsidiary and the UK parent company in cases of human rights violation outside of the UK. ${ }^{125}$

The attitude of the judiciary in environmental and petroleum sectorrelated cases in some instances has prompted aggrieved parties to turn to foreign jurisdictions to attempt to secure justice when it seems elusive in Nigeria. However, resorting to foreign jurisdictions to secure justice in environmental and petroleum sector-related cases has its merits and demerits. ${ }^{126}$ Instituting such actions in foreign jurisdictions can yield positive results ${ }^{127}$ such as providing alternative pathways to achieving what is otherwise inaccessible in Nigeria. ${ }^{128}$ Another advantage is that it guarantees the impartiality of the judiciary in any given case. ${ }^{129}$ However,

125 The UK Supreme Court rationale for this decision was that considering some factors such as competence, capacity and integrity of Zambia's justice system, evidence abounds that the Zambian claimants would almost certainly not get access to justice if the claims were pursued in Zambia; Some examples of Nigerian cases being heard in foreign jurisdictions include Esther Kiobel, et al. v. Royal Dutch Petroleum Company et al; Wiwa v. Royal Dutch/Shell; Wiwa v. Anderson; Wiwa v. SPDC, Okpabi v Shell; Amnesty International, "On Trial: Shell in Nigeria, Legal Actions Against the Oil Multinationals" (2020) < https:/ /www.amnesty.org/download/Documents/AFR4416982020ENGLISH.PDF> accessed 22 July 2020.

126 E.O. Popoola (n 119).

127 Wiwa v Royal Dutch Petroleum Company (2002) WL 319887 (SDNY 2002); Friday Alfred Akpan and Vereniging Milieudefensie vs. Royal Dutch Shell PLC and Shell Petroleum Development Company of Nigeria Ltd, District Court of The Hague [2013] ECLI.NL.RBDHA.2013.BY9854 Rechtbank Den Haag, 30-01-2013, C/ 09/337050/HA ZA 09/1580. These cases show that victims of environmental injustice in Nigeria can successfully sue multinational corporations in foreign jurisdictions. An example of such rights groups includes Friends of the Earth International that collaborated with Friday Alfred Akpan to successfully sue Royal Dutch Shell PLC and Shell Petroleum Development Company of Nigeria Ltd.

128 For instance, four women have sued Shell in Netherlands claiming compensation and a public apology for Shell's complicity in the arrest, unlawful detention and execution of their husbands in 1995. This would have been impossible in a Nigerian court because the Military Government in power at the time supervised the illegal arrest, detention and subsequent execution of the nine Ogoni activists.

129 E.O. Ekhator, "Improving Access to Environmental Justice under the African Charter on Human and Peoples' Rights: The Roles of NGOs in Nigeria" (2014) 22 (1) African Journal of International and Comparative Law 63, 73. 
this move can present some challenges as well. Prospective litigants must ensure that all other local remedies have been exhausted before they can approach some regional courts. ${ }^{130}$ Other disadvantages of seeking environmental justice in other jurisdictions is the high cost of litigation and jurisdictional challenges as some courts may not have the power to hear and determine some cases. This challenge of the high cost of litigation is usually solved by engaging and collaborating with established environmental and human rights groups who are willing to provide funding and legal services. ${ }^{131}$

Scholars have held divergent views on the general attitude of the judiciary in environmental matters before it. ${ }^{132}$ While some believe that the judiciary has exhibited sympathy towards victims of poor environmental decisions and have followed a pro-environmental protection approach in its method of adjudication by granting appropriate redress in such cases before the courts, ${ }^{133}$ others hold the contrary view that the judiciary has shown the tendency to be more tolerant of operators of the petroleum sector even when their liability is obvious by deferring to legal technicalities. ${ }^{134}$ It is contended that this dichotomy in views poses a challenge for policymakers to take a decisive stand on what action needs to be taken about improving the role of the judiciary or maintaining the status quo.

In recent times, it has been opined that the environmental crime liability of the government is highlighted in the lax regulatory regime ${ }^{135}$ and government's refusal to abide by the judgement of the African Commission on Human and Peoples' Rights in the case of SERAP v Nigeria. ${ }^{136}$ In that case, the court held that Nigeria's failure to monitor and enforce environmental laws violated the rights to health and a healthy environment under Articles 1 and 24 of the African Charter on Human and Peoples' Rights and this violation resulted in the breach of other

130 Article 50 of the African Charter on Human and Peoples' Rights.

131 Popoola (n 119).

132 Frynas (n 103) 199.

133 Frynas (n 103) 199, 219.

134 K.S.A. Ebeku, "Judicial Attitudes to Redress for Oil-Related Environmental Damage in Nigeria" (2003) 12(2) Review of European, Comparative and International Environmental Law 199, 207.

135 E.O. Ekhator, "Public Regulation of the Oil and Gas Industry in Nigeria: An Evaluation" (2016) 21(1) Annual Survey of International \& Comparative Law 43, 64.

136 SERAC v Nigeria (2002) ACHPR/COMM/A044/1. 
rights, including the right to an adequate standard of living and economic and social development. The decision in that case was reached in May 2002. It has been noted that the Nigerian government has also shown reluctance to implement environmental recommendations like the one made by UNEP on the environmental devastation of Ogoni land in 2011. ${ }^{137}$ In 2016, however, the federal government of Nigeria flagged of the environmental clean-up recommended by UNEP. Unfortunately, all kinds of controversies have trailed the process regarding the sincerity of the Nigerian government to effectively monitor the clean-up of the polluted environment.

\subsection{The Environmental Crime of Ecocide}

The term ecocide was derived from a combination of the Greek word oikos meaning house or home and Latin word caedere meaning destroy or kill. It is defined as the extensive damage to, destruction or loss of ecosystems of a given territory, whether by human agency or by other causes, to such an extent that peaceful enjoyment by the inhabitants of that territory has been severely diminished. ${ }^{138}$

The Stockholm Declaration stipulates that the natural resources of the earth must be safeguarded for the benefit of present and future generations ${ }^{139}$ by ensuring that the capacity of the earth to produce renewable resources must be maintained, and wherever practicable, restored or improved. ${ }^{140}$ States have been declared to have the responsibility to ensure that activities within their jurisdiction and control do not cause damage to the environment in furtherance of their sovereign right to exploit their own natural resources pursuant to their own environmental and development policies. ${ }^{141}$ This can be achieved by making environmental protection an integral part of the sustainable

137 C. Chuks-Ezike, "Environmental Crime Liability of the Nigerian Government in Its Oil Pollution Menace" (2018) 2(2) Environmental Risk Assessment and Remediation 1, 4.

138 S. Malhotra, "The International Crime That Could Have Been but Never Was: An English School Perspective on the Ecocide Law" (2017) 9 (3) Amsterdam Law Forum 49, 51; S. Mehta and P. Merz, "Ecocide-a New Crime Against Peace?" (2015) 17(1) Environmental Law Review 3, 5.

139 United Nations Conference on Human Environment, "Stockholm Declaration" (Stockholm, Sweden June 5 - 16 1972) Principle 2.

140 ibid Principle 3.

141 United Nations Conference on Environment and Development. "Rio Declaration" (United Nations, Rio de Janeiro June 14, 1992) Principle 2. 
development plan. ${ }^{142}$ The Rio Declaration further supports the enactment of effective environmental legislation. ${ }^{143}$ From the foregoing, it is argued that giving environmental crime recognition in environmental legislation in Nigeria, and punishing such activities will receive due international support because the United Nations Sustainable Development Goals 2015, promotes the essence of the Rio conference on environment and development. ${ }^{144}$

It is not surprising that the voices calling for the recognition of the environmental crime of ecocide have been on the increase in recent times. Higgins holds the view that no existing laws set out a proper duty of care for the earth as there is for human beings under the Universal Declaration of Human Rights. ${ }^{145}$ She argued that the earth has rights too, not to be polluted and the right to life. ${ }^{146}$ An increasing body of scientific and physical evidence points to the fact that the earth has reached a "tipping point" and is steadily approaching "planetary boundaries". ${ }^{147}$

While a lot is being done on the international scene to combat the obvious realities of climate change and general environmental degradation, compliance and enforcement remain a major challenge to the realization of the dividends of the efforts of the international community. ${ }^{148}$ Birnie has also argued that none of the conventions on environmental protection does more than state that the principles of

142 ibid Principle 4.

143 ibid Principle 11.

144 Specifically, goals 13 on climate action, 14 on life below water and 15 on life on land. Nigeria is a subscriber to the United Nations Sustainable Development Goals and

145 P. Higgins, Earth is Our Business: Changing the Rules of the Game (ShepheardWalwyn 2012) 224, 5

146 ibid.

147 S. Mehta and P. Merz, "Ecocide-A New Crime against Peace?" (2015) 17 (1). Environmental Law Review 3. The oceans are becoming warmer and ice caps melt, as carbon pollution constitutes to rise, more species of plants and animals are being lost than ever before. Indigenous people in many parts of the world are disappearing, population growth, worldwide destruction of ecosystems and climate change are accelerating this slide to the tipping point.

148 N. Gunningham, "Enforcing Environmental Regulations" (2011) 23(2) Journal of Environmental Law 169 where Gunningham stated categorically that for environmental legislation to "work" it must not only be well designed but also be efficiently and effectively enforced. 
liability should be developed. ${ }^{149}$ With the creation of the International Criminal Court in 2002 to try cases alleging crimes against peace: genocide, war crimes, crimes of aggression and crimes against humanity, ${ }^{150}$ there have been unsuccessful representations and proposals for the inclusion and recognition of the crime of ecocide as the fifth crime as an international war and peace crime. ${ }^{151}$

The definition of the term ecocide at the beginning of this section aptly describes the environmental tragedy that befell Ogoni land, the host community of the biggest petroleum exploration activity in Nigeria. The community is still labouring under the environmental devastation due to the delay in commencing the environmental clean-up ${ }^{152}$ ordered by the African Commission on Human and People's Rights (ACHPR) and recommended by United Nations Environment Programme (UNEP). ${ }^{153}$

The environmental crime of ecocide has not found expression in any environmental or petroleum sector law in Nigeria. However, crimes referred to as oil crimes have been written about in environmental and petroleum related literature. ${ }^{154}$ Such oil crimes include illegal oil bunkering or crude oil theft, sea piracy (attacks on the facilities and personnel of oil installations and rigs and private individuals), oil pipelines vandalism, fuel scooping, cross-border smuggling of petroleum products, oil terrorism/attacks on critical oil installations, kidnapping and hostage-taking of oil workers. ${ }^{155}$ While the term oil crimes has not

149 P. Birnie, "International Environmental Law: Its Adequacy for Present and Future Needs" in A. Hurrell and B. Kingsbury (eds), The International Politics of the Environment (Oxford Clarendon Press 1992) 666, 667.

150 Article 5 of the Rome Statute of the International Criminal Court, 2011.

151 Mehta and Merz (n 147) 4.

152 O.H. Yakubu, "Addressing Environmental Health Problems in Ogoni land through Implementation of United Nations Environment Program Recommendations: Environmental Management Strategies" (2017) 4 (2) Environments 28.

153 UNEP report on the environmental devastation in Ogoni land.

154 R. Adibe, E. Nwagwu and O. Albert, "Rentierism and Security Privatisation in the Nigerian Petroleum Industry: Assessment of Oil Pipeline Surveillance and Protection Contracts" (2018) 45(156) Review of African Political Economy 345; G. Ezirim, E. Onyemaechi and F.C. Onuoha, "The Political Economy of Nigeria's Power Sector Reforms: Challenges and Prospects, 2005-2015" (2016) 7(4) Mediterranean Journal of Social Sciences 443; F.C. Onuoha, G.E. Ezirim and C. Enyiazu, "Unbridled Pillage: The Political Economy of Oil Theft in Nigeria" (2017) 1(1) South East Journal of Political Science 19.

155 G.E. Ezirim, "Oil Crimes, National Security, and the Nigerian State, 1999 2015” (2008) 19 (1) Japanese Journal of Political Science 80, 86. 
been specifically used in any legislation in Nigeria, the Petroleum Production and Distribution (Anti-Sabotage) Act provides for the offence of sabotage. ${ }^{156}$ It is contended that the examples of oil crimes above, clearly fit what the Act envisages to be sabotage and the kind of resources that can be subject to sabotage under the law.

The Act refers to the offence of sabotage as any wilful act done with the intent to obstruct or prevent the production or distribution, ${ }^{157}$ procurement of petroleum products for distribution in any part of Nigeria ${ }^{158}$ or any wilful act done in respect of any vehicle or any public highway with intent to obstruct or prevent its use for the distribution of petroleum products, ${ }^{159}$ thereby causing any interruption in the production or distribution of petroleum products in any part of Nigeria. ${ }^{160}$ The Petroleum Production and Distribution (Anti-Sabotage) Act further defines petroleum products to include motor spirits, gas oil, diesel oil, automotive gas oil, fuel oil, aviation fuel, kerosene, liquified natural gases and any lubricating oil or greases or other lubricant. ${ }^{161}$ These are all products of crude oil. The penalty for this offence is death or imprisonment for not more than 21 years. ${ }^{162}$ It is contended here that while the term ecocide or oil crime is not expressly used in any environmental or petroleum related legislation, it is undeniable that the effects of oil crimes and sabotage bear a striking resemblance to the effect of the crime of ecocide on the human and natural environment.

\subsection{Recognizing the Rights of Nature}

While it does appear inconceivable that a corporation that commits an environmental crime can be subject to criminal sanctions, it is in fact achievable. This is because corporate criminal liability is not a strange phenomenon and has been practised in other jurisdictions. For example, in Brazil, the Law of Environmental Crimes was passed in 1998, ${ }^{163}$ detailing environmental crimes to include crimes against fauna, flora, pollution, crimes against planning and urban heritage and crimes against

156 Cap P12 Laws of the Federation of Nigeria 2010.

157 S 1 (1) (a) Cap P12 Laws of the Federation of Nigeria 2010.

158 S 1 (1) (b) Cap P12 Laws of the Federation of Nigeria 2010.

159 S 1 (1) (c) Cap P12 Laws of the Federation of Nigeria 2010.

160 S 1 (1) (c) Cap P12 Laws of the Federation of Nigeria 2010.

161 S 4 Cap P12 Laws of the Federation of Nigeria 2010.

162 S 2 Cap P12 Laws of the Federation of Nigeria 2010.

163 Federal Law 9,605/1998. 
government environmental management. ${ }^{164}$ The catch, however, is that for this offence to be an environmental crime, the natural resources will have to be accorded person status, making environmental protection of natural resources a binding state right. ${ }^{165}$

In some jurisdictions like India, New Zealand, Ecuador, Columbia, Bolivia, etc, nature and natural resources have been accorded human status $^{166}$ and consequently the right to be protected by the state just like human beings under human rights laws and the right to enforce such environmental rights under the law. ${ }^{167}$ It is argued that granting nature and natural resources person status will provide the foundation required to provide for criminal sanctions in the law in regard to environmental violations.

\subsection{Addressing Environmental Harm through the Criminal Justice Approach}

Corporate criminal liability in environmental regulation has long been in practice in jurisdictions like the United States of America. The US

164 R.F. Taffarello, "Corporate Criminal Liability Under Law of Environmental Crimes" (2018) < https://www.internationallawoffice.com/Newsletters/ Environment-Climate-Change/Brazil/Mattos-Filho-Veiga-Filho-Marrey-Jr-eQuiroga-Advogados/Corporate-criminal-liability-under-Law-ofEnvironmental-Crimes\#> accessed 21 July 2020.

165 J.R.M. Leite and M.D. Venâncio, "Environmental Protection in Brazil's High Court: Safeguarding the Environment Through a Rule of Law for Nature" (2017) (77) Sequência (Florianópolis) 29, 37.

166 Examples are New Zealand's Whanganui River was granted rights of personhood in 2017, India's Ganges River, Article 71 of the 2008 Constitution of Ecuador, essentially provides that nature has the right to integral respect for its existence and the maintenance and regenerations of its life's cycle's structure, functions and evolutionary processes. Examples of jurisdictions that have also recognized the legal rights of nature include Bolivia (Law of the Rights of Mother Earth and the Framework Law of Mother Earth and Integral Development for Living Well 2012); Columbia (A 2018 Supreme Court decision held the Columbian Amazon to be a subject of rights based on the Columbian Constitutional's Courts ruling that Atrato River had legal rights to be protected, conserved and restored); India (The 2018 Uttarakhand High Court decision declaring the animal kingdom to legal entities with rights, duties and liabilities of a living person); and the United States of America where Tamaqua Borough in Pennsylvania recognised the rights of natural communities and ecosystems in a 2006 ordinance) see G. Chapron, Y. Epstein and J.V. Lopez-Bao, "A Rights Revolution for Nature" (2019) 363(6434) Science 1392, 1393

167 C.D. Stone, Should Trees Have Standing? Law, Morality, and the Environment (Oxford University Press 2010) 264. 
Environmental Protection Agency indicts individual corporate officers in addition to the corporations. ${ }^{168}$ This was achieved by including the corporations in the definition of persons who may be prosecuted for the violation of environmental law. ${ }^{169}$ This has also been adopted in other sectors like the finance sector where individuals are held criminally liable for their actions on behalf of corporations. ${ }^{170}$

While the proposal to recognize environmental crime, however styled, may appear novel in the Nigerian academic and judicial discourse, it must be noted that some countries already recognize and have actioned the environmental crime of ecocide. ${ }^{171}$ Some of these countries include Vietnam, the Russian Federation, other former Soviet countries and the United States of America. ${ }^{172}$ In addition, other states have also proceeded to recognize the rights of nature, ecosystems and animals as academic literature has shown over time that human rights are linked to the environment and have continued to propose human rights approaches to environmental protection. ${ }^{173}$ Indeed, human rights, such as rights of indigenous peoples and intergenerational rights are often compromised by ecocide and the recognition of the environmental crime of ecocide

168 D. St John and others, "Environmental Crimes" (2020) 57(3) American Criminal Law Review 657, 665. The rationale behind the criminal prosecution of corporations engaging in environmental crime are (i) the harms posed by environmental crimes may be as significant as those posed by traditional crimes, (ii) the corporate environmental criminal may be just as morally culpable as traditional criminals and (iii) without criminal sanctions, corporations may view environmental sanctions as "a mere cost of doing business" that they may ultimately pass on to their customers. See page 666.

169 See U.S. Department of Justice, Justice Manual s 9-28.210 "Because a corporation can act only through individuals, imposition of individual criminal liability may provide the strongest deterrent against future corporate wrongdoing. Provable individual culpability should be pursued ... even in the face of an offer of a corporate guilty plea or some other disposition of the charges against the corporation, including a deferred prosecution or nonprosecution agreement, or a civil resolution."

170 S. Riyanta, "Corporate Criminal Liability in the Collapse of Bank Century in Indonesia" (2020) 8(1) Humanities and Social Science Letters 1, 1.

171 Mehta and Merz (n 147) 5.

172 A. Moffa, "Environmens Rea" (2018) 122 (2) Pennsylvania State Law Review 299,325 . The law is still evolving the range of punishment that can be levelled against entities.

173 M.R. Anderson, "Human Rights Approaches to Environmental Protection: An Overview" in A.E. Boyle and M.R. Anderson (eds), Human Rights Approaches to Environmental Protection (Clarendon Press Oxford 1998). 
will by extension protect the rights of human beings. ${ }^{174}$ Some countries such as New Zealand and Spain have accorded personhood status rights to great Apes in 1999 and 2008 and India extended the same status to dolphins in 2010. The protection of the environment improves the efforts at the protection of the rights of future generations. ${ }^{175}$

Environmental harms under Nigerian environmental legislation should be codified and created as crimes where offenders will be made to serve jail terms, without options of fine, especially where such offences result in the direct loss of human lives and irreversible destruction of the environment. This should be treated in the same way as the offence of murder or manslaughter because of the enormity of harm caused to society. Where the offender is a body corporate, the principle of "piercing the veil" could be applied to determine the officers in charge of such corporate bodies and hold them personally liable, ${ }^{176}$ especially in the jurisdiction where the offence is committed. This is because it is usually the case that for every action taken by a corporate body, there is an official directive and the highest officer who gives such directives could be held responsible for the consequences. Recognizing environmental crime and codifying it to give it the desired effect and force of law in Nigeria, will be a step in the direction of environmental regulation and protection. ${ }^{177}$ It is contended that since fines are the extent to which corporate bodies can be punished, deterrence may still not be achieved. In other words, liability of corporate bodies in form of fines will only be a part of the cost of doing business. ${ }^{178}$ As Lund and Sarin noted, "an enforcement regime that is limited in its ability to levy fines at an optimal level must rely on other forms of punishment - such as the imposition of liability on guilty individuals - to increase deterrence. Only then will corporate criminal

174 Mehta and Merz (n 147) 5 The 2008 Constitution of Ecuador in chapter 7 , recognizes the Rights of Mother Earth, Bolivia in 2010 adopted the rights of Mother earth, granting nature the right to life, biodiversity, water, clean air, equilibrium, restoration and freedom from pollution.

175 Opposa v Factoran (1993) GR No 101083.

176 Corporations can also be vicariously liable for the acts of their officers under s 66 (1) and (3) of the Companies and Allied Matters Act Laws of the Federation of Nigeria 2010.

177 M.T. Okorodudu-Fubara, "Statutory Piercing of the Corporate Veil Under Environmental Protection Laws" (1998) 2 Modern Practice Journal of Finance \& Investment Law 1.

178 D. St John and others, "Environmental Crimes" (2020) 57(3) American Criminal Law Review 657, 666. 
punishment be something more than a cost of doing business."179

Furthermore, environmental pollution incidents due to petroleum operations could be made strict liability offences, following the principle laid down in the English case of Rylands $v$ Fletcher ${ }^{180}$ where the only proof required will be the fact that the petroleum did in fact spill and no other proof will be required and liability will lie on the oil company that has brought the oil upon the land. This approach will put the onus of safeguarding the petroleum from escaping and the protection of the installations from vandals on the petroleum sector operators. ${ }^{181}$ It has been argued that making environmental crime a strict liability offence has some advantages. These advantages include the potential to promote the public interest goal inherent in environmental legislation, act as a deterrent which encourages the quality of environmental risk prevention measures, increase the ease of prosecution, which in turn improves the deterrent effect and strengthens accords in public-private partnerships. ${ }^{182}$ This is vital as it has been shown over time that establishing a claim in petroleum-related environmental harm can be quite technical and much more is usually required for the plaintiff to prove the liability of the defendant. ${ }^{183}$

The likelihood of possible criminal sanction will also compel oil companies to ensure the prompt replacement of oil facilities that have the tendency to fail, as and when due. Such proactive steps will forestall equipment failure as some of the oil facilities being used in Nigeria have been in use for a very long time, some even since the commencement of exploration activities in the 1950s. The oil companies should, in conjunction with the regulatory agencies, take seriously the task of creating awareness of the imperative of safeguarding oil installations and the dangers of interference with such installations by the citizenry.

179 D.S. Lund and N. Sarin, "The Cost of Doing Business: Corporate Crime and Punishment Post-Crisis" (2020) (20-13) Penn Law: Legal Scholarship Repository $1,49$.

180 Rylands $v$ Fletcher ý (1868) LR 3 HL 330.

181 Umudje \& Anor $v$ Shell BP Petroleum Development Company of Nigeria Limited (1975) 9-11 SC 95. In that case, the plaintiffs successfully relied on the strict liability doctrine and the Supreme Court held that the defendants were liable for their crude oil waste that escaped onto the plaintiff"s land, polluting their ponds, and killing their fish in the course of is oil exploration activities. See also Shell Petroleum Development Company v. Anaro \& Ors (2015) LPELR-24750.

182 Bell and others (n 40) 273.

183 Ayadi \& Ors v Mobil Producing Nigeria Unlimited (2016) LPELR - 41599. 
Flowing from the above, codifying and recognizing the environmental crime of ecocide will not be a strange move, but one in the right direction towards achieving the much-desired environmental protection and by extension, the protection of human rights of present and future generations and the rights of nature.

\section{CONCLUSION}

The long history of poor environmental practices in the Nigerian petroleum industry fall below the various national and international environmental standards and shows the urgent need for action towards a more effective environmental regulation and protection. While environmental and petroleum-related laws exist in Nigeria, several loopholes exist in those laws that make it difficult to enforce. ${ }^{184}$ Recent literature advocate the need for a more collaborative approach to environmental regulation, however, this does not remove the need for a more effective enforcement regime as history has shown that some offenders can be recalcitrant especially when they are major corporations. To create a more sustainable environment and improve environmental protection and regulation, environmental legislations that lack the coherence required to institute a hermetic case against an offending party should be reviewed as a matter of urgency because environmental problems across all areas, are now at the stage where they are a threat to humanity's survival. ${ }^{185}$

Taking the proactive step of criminalizing environmental harm in Nigeria will attenuate the chances of Nigeria being regarded as part of the global environmental problem when eventually the international community wakes up to the reality of the exigencies of this crime. This is more so because Nigeria is the largest producer and exporter of crude oil in Africa. Moreover, waiting for the international community to provide a solution without taking into consideration the social, political and economic developmental pace of Nigeria might not be the best way to go as the one-size-fits-all approach has never worked in such matters. ${ }^{186}$

184 C. Chuks-Ezike, "Deficient Legislation Sanctioning Oil Spill in Nigeria: A Need for a Review of the Regulatory Component of Petroleum Laws in Nigeria and the Petroleum Industries Bill" (2018) 7(1) International Journal of Environment and Sustainability 30, 40.

185 R. White, Crimes Against Nature: Environmental Criminology and Ecological Justice (1st edn, Routledge 2013) 328, 9.

186 N. Gunningham (n148) 194. 
It is our submission that addressing the concerns discussed in this article will go a long way in improving the environmental practices in the petroleum sector in Nigeria. It will also show good faith on the part of the Nigerian government in its commitment to tackling systematic environmental destruction in the country that has hitherto prevailed in the operations of the petroleum sector. This will consequently help the Nigerian government to contribute more towards achieving the United Nations Sustainable Development Goals by the year 2030 through other petroleum sector operators. 